\title{
Relationship Contracting: The South Australian Experience- A Case Study
}

Jian Zuo (School of Natural and Built Environments, University of South Australia, Adelaide, Australia)

GeorgZillante (School of Natural and Built Environments, University of South Australia Adelaide Australia)

\section{ABSTRACT}

The construction industry has long been accused of poor performance. The confrontational attitude of its members and the resultant adversarial atmosphere has been identified as a major factor responsible for this poor performance. A cultural change is required to remove these barriers and to promote optimum project outcomes. Relationship contracting is promoted as a way to support the shift from the adversarial culture to the co-operative and collaborative culture within the industry and the project team.

The Adelaide Convention Centre Extensions project was the first in South Australia to be procure und $r$ the principles of relationship contract1ng. Usmg the case study approach, this paper reviews the form of relationship contracting used in this milestone project. The paper documents the lessons learned from this project and makes recommendations that can lead to improvements for future projects.

Keywords: Relationship contracting, South Australia, win-win approach, best-for-the-project

\section{RELATIONSHIP CONTRACTING -}

\section{TARGETING THE CULTURAL SHIFT}

The public image of the construction industry is generally poor. It has long been notorious for its poor performance and confrontational disputes. Construction projects are usually procured by competitive tendering. This competitive approach, the different objectives of the contracting parties and the practice of improper risk allocation, has often resulted in the creation of an adversarial relationship. The need for process improvement and cultural shifts has been advocated as a means of improving the effectiveness and competitiveness of the construction industry (APCC 1997, RCBCl 2002, Latham 1994, Egan

1998 and relationship contracting is often recommended to support this cultural shift. By fostering collaborative relationships between project participants, relationship contracting has become the most popular procurement approach in the public sector over recent years.

The term Relationship Contracting is used to illustrate delivery systems that concentrate on relationships between participating parties in a construction contract, rather than just on the project-specific requirements i.e. achieving the objectives of the contract (Quick 2002). In relationship contracts there is a formal expression of the relationship between participating parties.

The Australian Constructors Association (ACA), a group whose member companies are all leading construction industry organisations, defines Relationship Contracting as:

\begin{abstract}
"..a process to establish and manage the relationships between the parties that aims to: remove baffiers; encourage maximum contribution; and allow all parties to achieve success." (Australian Constructors Association. 1999, p.4)
\end{abstract}

From the above definition, it can be discerned that the most important element of relationship contracting, as the name suggests, is the relationship between the parties involved in the project. Reasons to develop and sustain a good relationship between the participating parties include:(a) to remove the barriers (to outstanding outcomes) that exist in a conventional contract. and (b) to encourage maximum commitment and contribution from all parties and individuals. The most important facet of relationship contracting is to enable (or at least aim to enable) all parties to achieve success. Such a "win-win" approach is achieved by the alignment of the objectives of parties (individuals) and gainshare/painshare 

mechanisms. This is a significant departure from the traditional 'win-I ose' scenario.

A relationship contract could be any contract that seeks to emphasise the relationship between the parties in order to achieve optimal outcomes for the job to be done (Quick 2002). There are two kinds of relationship contracts that are currently popular within the industry, viz, alliancing and partnering (Rawlinson \& Cheung 2004; Ross 2001). Alliancing, where the parties form a cohesive entity, is characterised by all parties jointly sharing the risk and reward. This gainshare/painshare scheme is the key difference from partnering, where the parties still retain independence and may individually suffer or gain from the relationship (Walker et al. 2002).

Although alliancing has been applied in the Australian industry for more than ten years, all those projects have been of a complex engineering nature rather than building/construction projects. The National Museum of Australia (the Acton Peninsula Alliance) was the first building project in the world to employ alliance contracting. This project was identified as a successful alliancing project by the Australian National Audit Office for its excellent achievements in relation to budget, time, quality, design integrity, and risk management etc (Australia National Audit Office 2001).

\section{THE PROJECT-THE ADELAIDE CONVENTION CENTRE EXTENSIONS}

In South Australia, the Adelaide Convention Centre Extensions project was the first to be procured under the principles of relationship contracting (DAIS 2001).

Being established in 1987 as the first dedicated convention venue in Australia, the Adelaide Convention Centre was complemented by the development of the Exhibition Hall in 1990. The Ade!aide Convention Centre p!ays a critic'Ill role in the development of the convention, exhibition and meetings market in South Australia and is a vital contributor to South Australia's \$2.7 billion tourism industry (The Public Works Committee 1999a). This industry has continued to grow and is currently (2005) worth just under $\$ 3.7$ billion (The Advertiser 4/11/05 p28).

Conventions have been growing in size and increased exhibition space and banquet space was needed to support the existing conference facilities and provide more flexibility in operation. Expansion was essential to attract new business and, to maintain its position as one of the top 10 convention centres in the world outside the United States (The Public Works Committee 1999a).

The project scope included:

- Plaza level

o $7,200 \mathrm{~m}^{2}$ exhibition and banquet halls

o $1,800 \mathrm{~m}^{2}$ of lobby and prefunction space

o Services storage and support spaces

o Western loading dock area

- Terrace level
o 3 banquet rooms
o 110 seat bistro
o New kitchen and support areas

As a large construction project, The Adelaide Convention Centre Extension project involved significant risks. The project had a very strict target completion date and budget and was to be built over an operating railway station. In order to better handle these risks, the form of relationship contracting adopted was chosen with the view to selecting the contractor best qualified to deliver the project and to achieve optimum outcomes. 


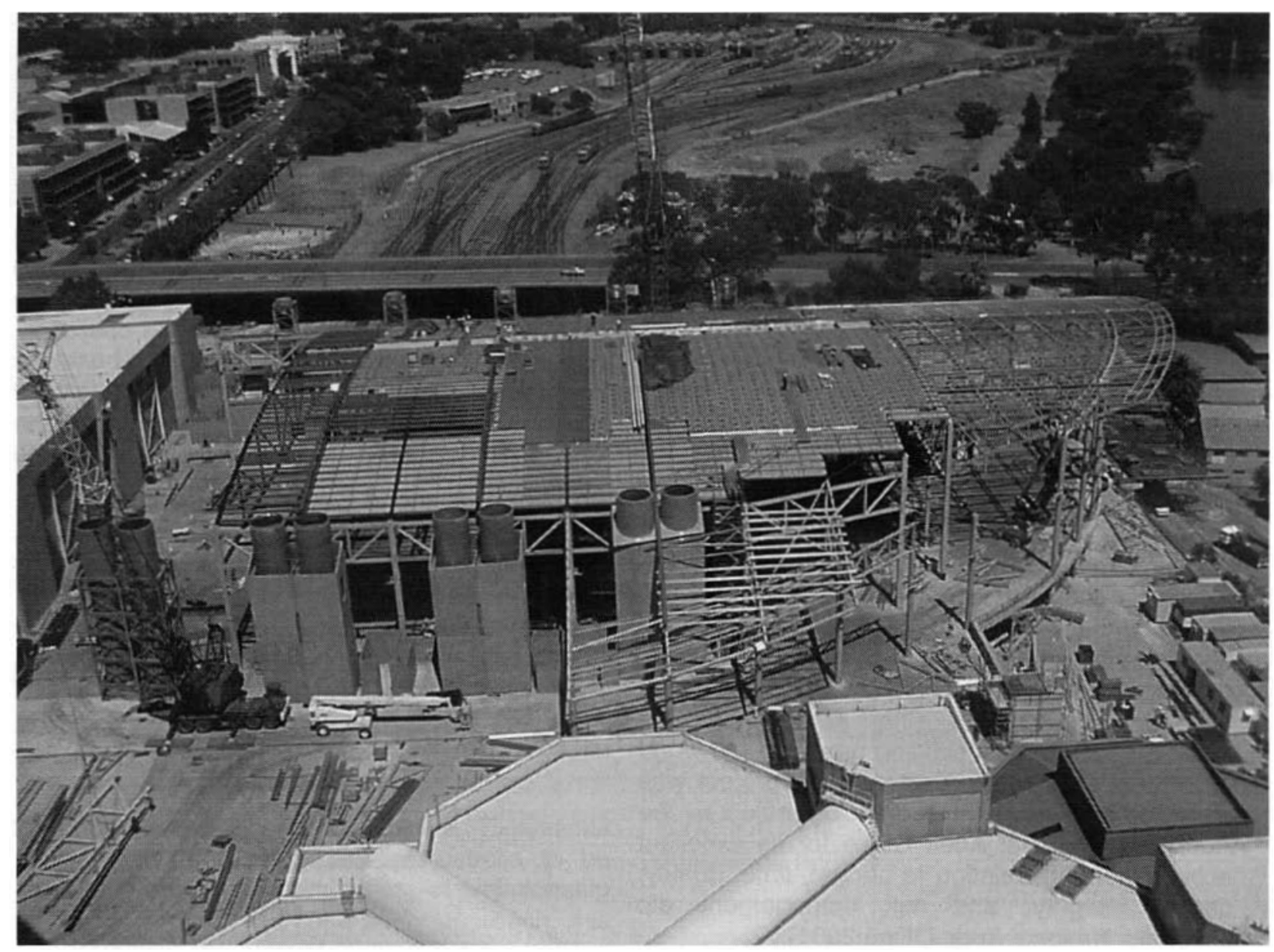

Figure 1: Progress of the ACC EXT-over the track of the railway

Courtesy of Mr. Paul Schlosser; Baulderstone and Hornibrook

\section{RESEARCH PROCESS}

This research employed a case study approach to review South Australia's experience with the application of relationship contracting in the construction industry. As the first project to be procured using this alternative approach, the Adelaide Convention Centre Extensions project made for an ideal case study.

Six project participants were interviewed. They were from the key participating parties namely: the government agency, the project management consultant. the collaborative consultant, the

managing contractor, the architect and the engineering consultant. They were chosen because (1) they had significant involvement with the project; (2) they were available when this research was conducted; and (3) the multi-source of information improves the reliability of the research.
They were asked to comment on their experience with the relationship contracting approach used on the project. Specifically, they were asked about the benefits and the problems of relationship contracting.

After the interview process, some project documents were evaluated in order to confirm the statements made by the interviewees. These documents included:

- Tendering documents

- High performance team building workshop reports

- Project completion workshop report

The research findings are reported in the following sections. 
THE STRUCTURE OF THE PROJECT ORGANIZATION

The organization structure was established with an Integrated Management Team (IMT), a Project Control Group (PCG), and a Site group (see Figure 2).

The Integrated Management Team was responsible for:
- decision making in regard to matters that impacted on the project, including the collaborative relationship;

- providing advice to the Principal;

- ensuring corporate management support; and

- ensuring adequate resources were provided.

The IMT comprised senior executives of the client, end user, purchaser and risk manager (DAIS), project manager, primary consultant architect, cost manager and managing contractor (see Figure 3).

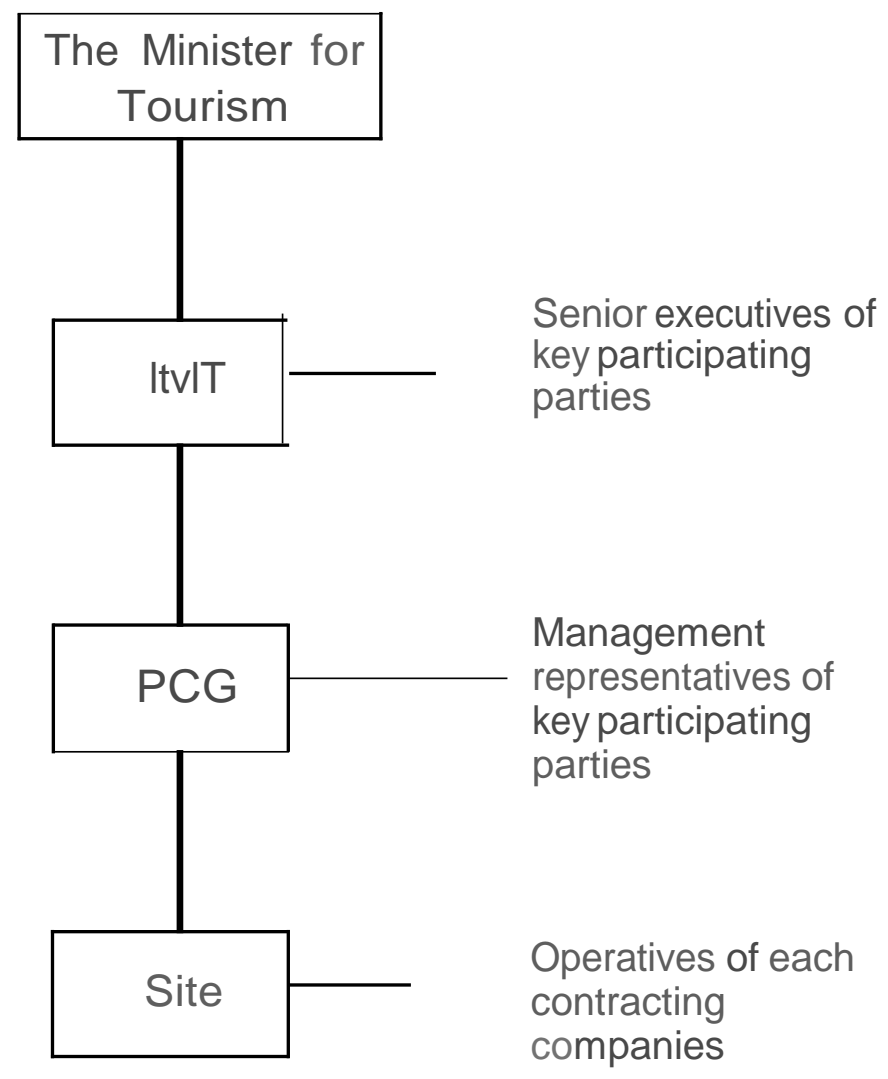

Figure 2: The structure of the project organization 


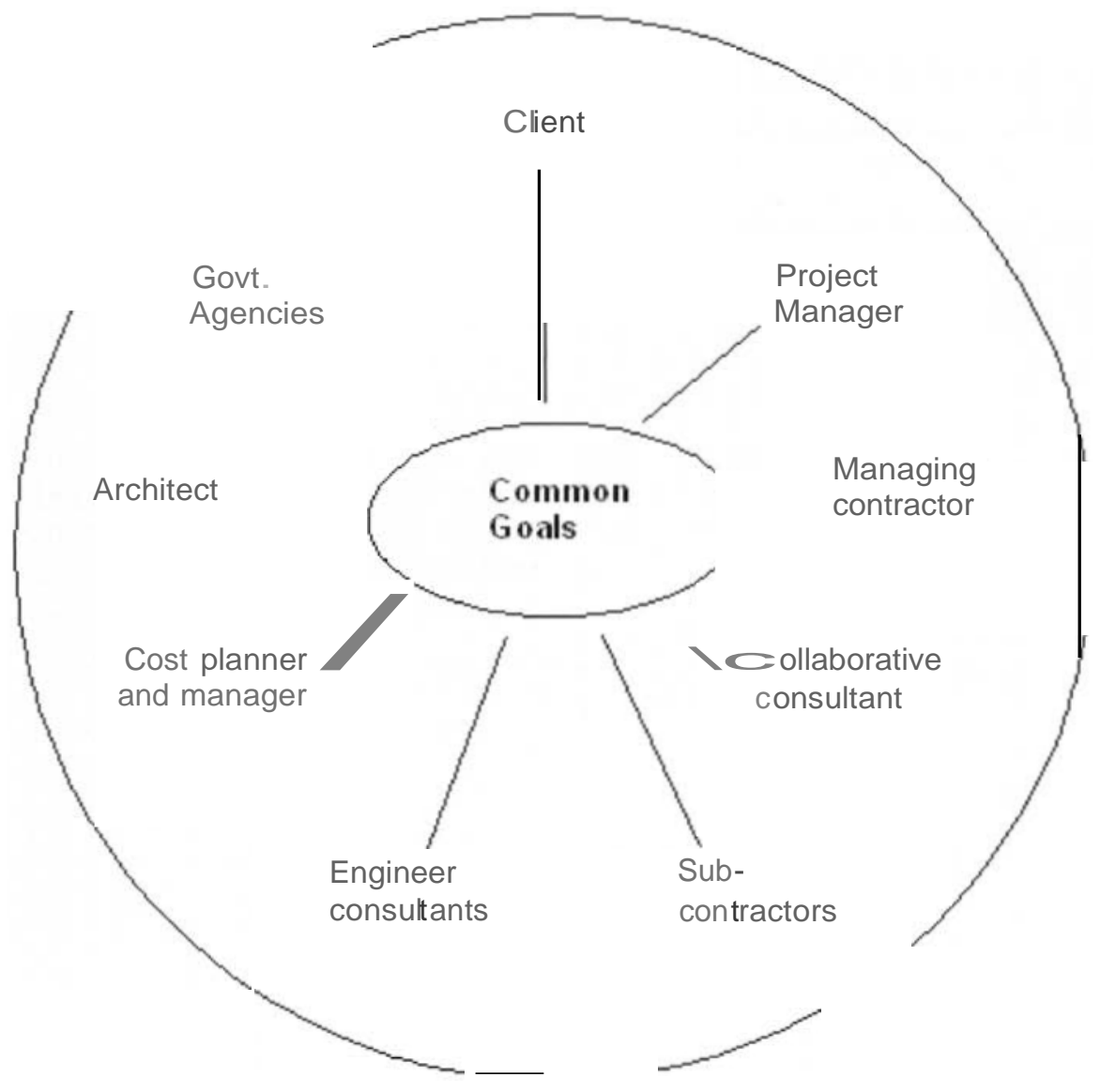

Figure 3: The structure of the Integrated Management Team

Reporting to the IMT was the Project Control risks and have common goals as objectives for Group (PCG) compnsmg management the project which they work very hard to achieve. representatives of the same organizations. The PCG was responsible for the day-to-day management of the project.

\section{THE COLLABORATIVE CONTRACT}

The Site group was composed of operatives from each of the contracting companies.

A true alliance usually starts with no contract, no consultants and no appointments. Subsequently, a contractor and all consultants are appointed in one hit. This 'true" alliance contracting is at the

Traditionally, a hierarchical organizational 'top end of the spectrum' of the relationship structure is used for construction projects. In such arrangements, one party, usually the client sits on the top of the structure and dominates the process. In the ACC EXT project, a nonhierarchical structure was established from the beginning of the project with all participating parties having an equal role. Under this system no party can dominate the team and all parties work together under the principles of relationship contracting. Similarly, all parties share ownership of the project outcomes by taking part in the decision making process. They share profits and 
These consultants subsequently became members of the selection panel used to choose the managing contractor and the sub-contractors.

The potential contractors were asked to submit documents to illustrate how they satisfied the prequalification requirements, which required contractors to meet a set of benchmarks under the following criteria (The Public Works Committee 1999b):

- technical capability

- financial capacity

- quality assurance

- human resource management

- $\mathrm{OH} \& \mathrm{~S}$

- skills formation

- industry initiative They were also required to illustrate their with those adopted in the world-first alliancing capabilities to cooperate with other project team building project - The National Museum of members. Innovative tendering process, Australia. The study of the collaborative process including interviews and workshops were used in the National Museum of Australia project conducted in this projed.

The differences between the traditional lump sum contract and the collaborative contract adopted in this project (illustrated in Table 1) were deduced from the interviews and the project documents.

All six interviewees stressed that best-for-project participants were selected via this approach.

"... each party had the appropriate expertise and skills to work out the allocated tasks. Furthermore, all participants were willing to help each other during the project process and were prepared to shift their individual objectives/interests to focus on common goal."

$" . .$. there is a high level of trust across the project team... All parties committed themselves towards achieving optimum project outcomes."

\footnotetext{
${ }^{1}$ The detailed information about the contractor tendering process in the collaborative contract will be introduced in another paper.
}

"The project team is unanimous in its assessment that the collaborative approach contributed to these successes" (DAIS report, 2001).

Selection of suitable partners is very important for the success of relationship contracting projects (Walker and Hampson 2003). Partner selection is encompassed with relationship development (Davis, 2004). During the selection process, the purpose of the relationship is defined, boundaries are established and value is created and maintained. Other relationship development exercises include agreement of ground rules, knowledge transfer, common goal attainment and all these lead to increased trust (Davis, 2006).

This selection process and the set of selection revealed that the principles of Alliancing and the selection process facilitate high level of trust and high level of commitments from all parties (Walker and Hampson 2003).

\section{PROJECT OUTCOMES}

The extension project has achieved excellent outcomes. It was awarded the best project in the category - 'Commercial Industrial building over $\$ 10$ million' by the Australian Institute of Building (AIB). The judges" comments include:

'The Adelaide Convention Centre is an outstanding example of commercial building."

'The complex architectural and structural design of this huge addition to the Riverbank Precinct called for innovation in construction and excellence in management of a very large workforce."

'The builder was required to work alongside the operating Adelaide Convention Centre, Hyatt Hotel, Adelaide Festival Centre and over the Adelaide Railway Station tracks. This created a multitude of operational and 
environmental challenges all of which were successful overcome."

"(The managing contractor) is justly proud of its collaborative approach to the project which is an asset to the State and a fine example of high-quality construction and outstanding management of building project delivery".
There is a mixture of great pride and satisfaction that the objectives of implementing the collaborative contract were achieved. The risks of industrial action, environment and safety were managed to very low levels (DAIS report 2001).

The project outcomes are illustrated in Table 2.

\begin{tabular}{|c|c|c|}
\hline & Traditional Lump Sum Contract & Collaborative Contract \\
\hline \multirow[t]{2}{*}{ Tendering } & $\begin{array}{l}\text { Decisions are made by selection } \\
\text { panel, not involving tenderer. }\end{array}$ & $\begin{array}{l}\text { Interviews and workshops are part of the } \\
\text { selection process, which give the tenderer } \\
\text { opportunities to show their capabilities. }\end{array}$ \\
\hline & Price is the only sel ection criteria. & $\begin{array}{l}\text { Price is one of the selection criteria but does } \\
\text { not have the highest priority. The capability to } \\
\text { cooperate with other project team members is } \\
\text { given the highest priority. }\end{array}$ \\
\hline \multirow[t]{5}{*}{ Ownership } & $\begin{array}{l}\text { Without incentive and reward } \\
\text { scheme; only penalties clauses are } \\
\text { included in the contract for } \\
\text { not achieving the project objectives. }\end{array}$ & $\begin{array}{l}\text { Incentives are included in contract to reward } \\
\text { optimum performance and encourage } \\
\text { innovation. }\end{array}$ \\
\hline & $\begin{array}{l}\text { Nil accountability for final product } \\
\text { other than producing what is } \\
\text { documented. }\end{array}$ & $\begin{array}{l}\text { Everyone makes the decision and has to be } \\
\text { accountable for success or failure. }\end{array}$ \\
\hline & $\begin{array}{l}\text { All participants attempt to transfer } \\
\text { the risks to the other party. }\end{array}$ & All participants share the risks. \\
\hline & $\begin{array}{l}\text { Contractor has minimal say in the } \\
\text { decision making process. }\end{array}$ & $\begin{array}{l}\text { Contractor is proactively involved in the } \\
\text { decision making. }\end{array}$ \\
\hline & $\begin{array}{l}\text { Contractor is engaged solely to } \\
\text { construct according to the } \\
\text { documentation. }\end{array}$ & $\begin{array}{l}\text { Contractor is engaged in a very early stage } \\
\text { and could affect the design, documentation } \\
\text { and construction of the project. }\end{array}$ \\
\hline
\end{tabular}

Table 1 The differences between traditional and collaborative contract

(Adopted from DAIS report 2001 and incorporated with the interview notes) 


\begin{tabular}{|c|c|c|}
\hline Objective & Achievements & Notes \\
\hline Time & $\begin{array}{l}\text { Ready for use on } 31 \text { Aug } 2001 \text { and } \\
\text { completed } 19 \text { October } 2001 .\end{array}$ & $\begin{array}{l}\text { Pre-scheduled International Wine } \\
\text { Conference held on time. }\end{array}$ \\
\hline Budget & $\begin{array}{l}\text { Over budget by an estimated } \$ 7.4 \mathrm{M} \text { or } \\
8.7 \% \text {. }\end{array}$ & $\begin{array}{l}\text { Budget overrun between } 10 \% \text { and } 30 \% \\
\text { is common for one-off iconic public } \\
\text { projects in Australia. }\end{array}$ \\
\hline $\begin{array}{l}\text { Cost per } \\
\text { square } \\
\text { metre }\end{array}$ & $\$ 3,635 / \mathrm{m}^{2}$ excellent value for money. & $\begin{array}{l}\text { The Melbourne Exhibition Centre } \\
(\$ 3,511 / \mathrm{ml} \text { the Glasgow Scottish } \\
\text { Exhibition and Conference Centre } \\
\left(\$ 4,130 / \mathrm{m}^{2} \text {, Sydney Convention \& }\right. \\
\text { Exhibition Centre }\left(\$ 4,214 / \mathrm{m}^{2}\right) \text {, Hong } \\
\text { Kond Convention Centre }\left(\$ 456 / \mathrm{m}^{2}\right)\end{array}$ \\
\hline Quality & $\begin{array}{l}\text { Errors and om } 1 \text { ssions account for } 85 \% \\
\text { contingency expenditure or } 10 \% \text { of } \\
\text { construction value. }\end{array}$ & $\begin{array}{l}\text { International standard facility achieved. } \\
\text { High levels of re-documentation as part } \\
\text { of savings strategy. Some re-work of } \\
\text { construction. }\end{array}$ \\
\hline Safety & 6 lost time accidents. & $\begin{array}{l}\text { Design for construction and operational } \\
\text { safety achieved. }\end{array}$ \\
\hline Environment & $\begin{array}{lcrr}\text { Limited design } & \text { for } & \text { environmental } \\
\text { sustainability } & \text { but some } & \text { incremental } \\
\text { improvement } & \text { above } & \text { benchmark. } \\
\text { Environmental } & \text { management } & \text { plan } \\
\text { developed, externally audited } & \text { monthly, } \\
\text { environmental } & \text { awareness } & \text { training } \\
\text { implemented. } & & \end{array}$ & $\begin{array}{l}\text { Environmental risks were managed to } \\
\text { very low levels. } \\
\text { For air conditioning purposes, the } \\
\text { design incorporates a central chilled } \\
\text { water system. This has a higher capital } \\
\text { cost than alternative packaged air } \\
\text { conditioning units ( } \$ 1.0 m \text { to } \$ 1.2 \mathrm{~m}) \text { but } \\
\text { energy consumption costs are } 10-15 \% \\
\text { lower and carbon dioxide emissions are } \\
\text { signficantly less for the central system, } \\
\text { resulting in a more economical } \\
\text { and environmentally friendly life cycle } \\
\text { cost for this aspect of the project. }\end{array}$ \\
\hline $\begin{array}{l}\text { Contractual } \\
\text { and } \\
\text { Workplace } \\
\text { Relations }\end{array}$ & $\begin{array}{l}\text { No disputes with the managing contractor; } \\
\text { disputes existed with two sub-contractors; } \\
\text { higher level of respect for stakeholder } \\
\text { profitability. }\end{array}$ & $\begin{array}{l}\text { Subcontractors acknowledge the project } \\
\text { was a great experience. They did not } \\
\text { have a real lcarror or "stick". }\end{array}$ \\
\hline
\end{tabular}

Table 2 The outcomes of the Adelaide Convention Centre Extensions project, Source: DAIS report 2001

All the interviewees stressed that the collaborative contract approach was a significant contributor to these successes. They suggested that the principles of relationship contracting (in this project: collaborative contract) should be applied in future projects.

The relevant government agency (DAIS) also documented the success of this project as:
"Without doubt the collaboration contract achieved its fundamental aim - to manage and m1t1gate the nsKs, the Adeiaide Convention Centre Extensions project is a showcase to the project team and the contract's success." (DAIS report, 2001)

The Relationship approach has ensured that potential claims and disputes have been worked through without a major conflict (Memo for ACC 
EXT project, by Mr. Gary Dare, the construction manager of this project).

All interviewees were extremely satisfied with the relationship with other participating parties. From their perspective, all parties were willing to help each other yet did not hesitate to point out any potential issues. This 'early warning" characteristic of the project culture supplemented the collaborative culture with project participants co-operating with each other to resolve each issue as it arose during the project process. This did not, however, deter them raising questions about the design and construction process.

"These are positive signs of the internal culture of the project team... it is not good to hide any concerns... talking straight is to help rather than to challenge others..." (from interview notes)

The significant achievements of the Adelaide Convention Centre Extensions project has resulted in more major public projects in SA being procured via this alternative approach. Carr and Exton have previously described (Clients Driving Innovation International Conference 2004) the success of relationship contracting on the Lyell McEwin Heath Service Redevelopment Stage A project.

\section{LESSONS LEARNED}

Although this project has achieved optimum outcomes, there are still some problems that need to be addressed for future projects that are procured using this approach. The lessons learned from this project (based on interview findings and the reports from relevant government authorities e.g. DAIS \& The Public Works Committee), are illustrated as follows:

Firstly, the preferred project culture only spreads amongst the major parties in the project (main level\} e.g. main contractor, primary consultant, the client. Sub-cultures that are different from this project culture exist at the sub-level e.g. subcontractor, other consultants. For instance, one interviewee stated:

"Straight talk was achieved at the core team level......however, sub-contractors found it very difficult to be upfront and honest and discuss the problems encountered at the site meeting. Instead, sub-contractors preferred to show the problems to the managing contractor and to try and resolve the problem via the managing contractor."

Developing and crafting a coherent project vision helps to shift the subcultures to be more consistent with the universal project culture. The project vision encompasses three factors: vision clarity, vision support and vision stability. Each of these components is positively associated with success in certain types of innovation (Lynn 1999; Lynn and Akgun 2001).

Project participants may have a variety of motivations, aspirations and agenda which may often clash with best-for-project objectives. Christensen and Walker (2004) argue that project vision makes a significant contribution towards project success.

Developing a project v1s1on relies on clearly defining project goals. Creating an effective project vision requires excellent communication skills and a deep understanding of each stakeholder's objectives. Accordingly there is a need to facilitate the inputs of all stakeholders to ensure that all insights are taken into account.

It is suggested that more workshops and training should be conducted to let the subcontractors become more aware of and understand the principles of collaborative contracting and how they should act under the different circumstances. This could be a part of the relationship development process, which is a core driver for a successful relationship contract (Davis, 2004).

Secondly, it is very important to have realistic project goals. As interviewees commented:

\begin{abstract}
"Unrealistic project goals were detrimental to the relationship between project team members. Unrealistic project goals were responsible for the adversarial behaviours of project participants." (from interview notes)
\end{abstract}

Accordingly, it is suggested that realistic project goals and objectives be established and maintained and that they be reviewed and reset if they become unachievable. 
Thirdly, the co-location of the whole project team Fifthly, more resources and commitments from on site is conducive to achieving effective and the client are required for the success of efficient communication. These merits were relationship contracting projects. Other verified at the National Museum project in participating parties also need to invest resources Canberra. In the Adelaide project, this was not in the very early stages of the project. This will achieved until later in the construction program result in better profit returns because the whole when key representatives of the architect were project team has a better understanding of the co-located on site with the managing contractor. project.

Even this partial co-location was recognized as an important contributing factor to successful completion by all interviewees. They stressed that "co-location of the design team with the construction team facilitates an integrated approach to issue resolution and identification of design and construction opportunities."

'There was an acceleration of attending to information request, of design change implementation and a wider ownership of the design changes." (DAIS 2001)

Fourthly, similar selection criteria should also be considered when appointing consultants. In this project, all consultants were already appointed before the contractors were chosen. No explicit criteria cover the collaborative capabilities of the consultants when they are engaged. It is suggested that the client should also consider this when selecting consultants. This ensures that the consultants are prepared to work in a collaborative setting. Similarly, they will be entitled to be 'qualified' selection panel members responsible to assess the collaboration and The number of interviewees that agreed with cooperation capabilities of the managing each learned Iesson is illustrated in Figure 4. contractor and sub-contractors.

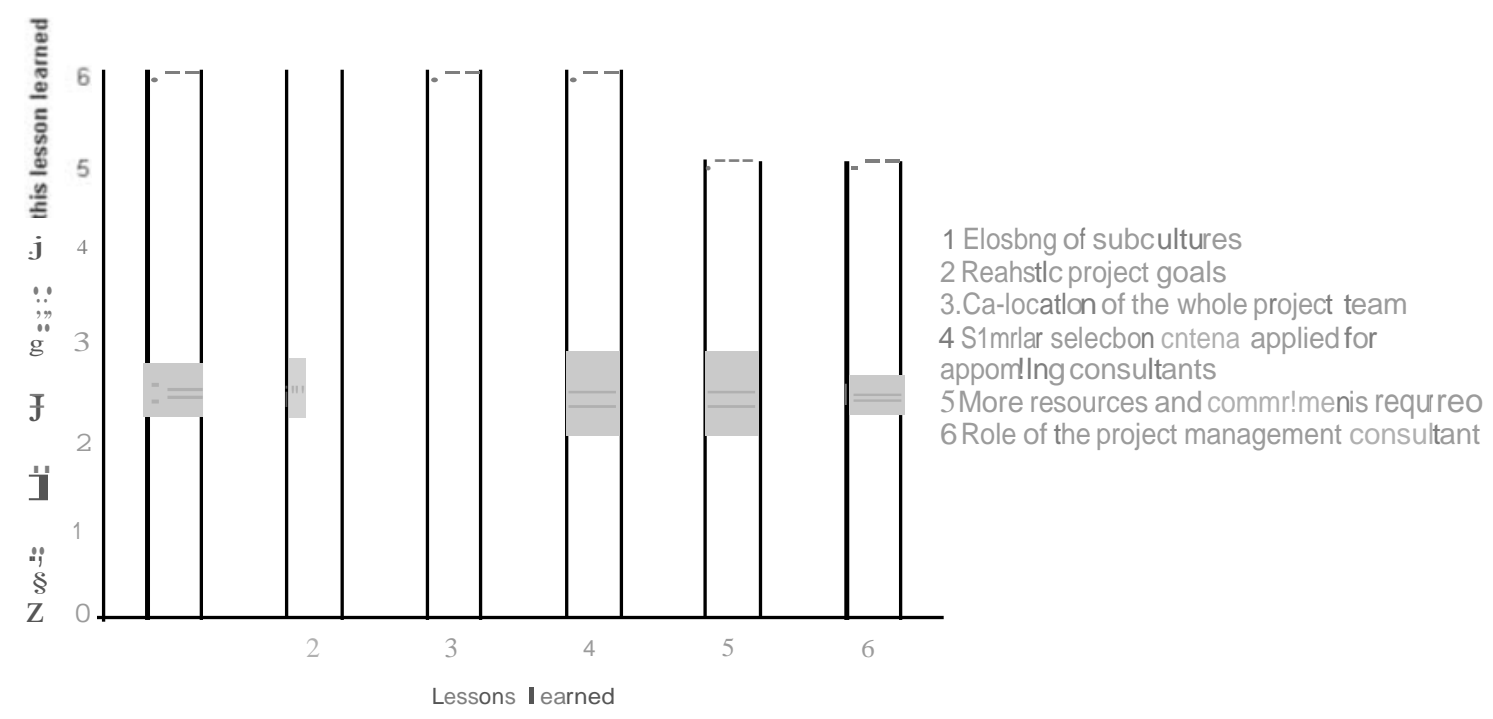

Figure 4: Lessons learned from the ACC EXT project 


\section{CONCLUSIONS}

As the first project to be procured via relationship contracting in South Australia, the Adelaide Convention Centre Extensions project has achieved optimum outcomes. The facility was available for the pre-scheduled International Wine Conference on the 31st Aug 2001. The result of each project objective was generally better than the agreed benchmark. At completion there were no disputes with the managing contractor. There was a genuine involvement in design, construability and innovation $\mathbf{b}$ the subcontractors. The project team was unan1mous in its assessment that the collaborative contract approach was a significant contributor to these successes.

The lessons learned from this project can be applied to future projects; however there is still room for further improvement.

The research raised some issues regarding subcontractors e.g. the established project culture stopped at the subcontractor level and it was very important to choose the 'right' subcontractors. This research did not look at participants at the sub-contractor level. Future research is required to fill this gap.

\section{ACKNOWLEDGEMENTS}

The authors would like to acknowledge the contributions from the industry professionals by attending the interviews and providing project documents. For reasons of confidentiality their names cannot be listed.

Similarly the authors would like to acknowledge Mr. PaulSchlosser and Mr. Gary Dare for their assistance in providing the work in progress photographs and other project doc ments? the Adelaide Convention Centre Extens1ons proJect.

The authors also would like to acknowledge Dr. Peter Davis's valuable comments on the relationship development and management in construction projects.

\section{REFERENCES}

'\$3.3bn boon for the state'2005, The Advertiser, p. 28.

Australian Constructors Association. 1999, Relationship contracting : optimising project outcomes, The Association, Sydney, N.S.W.

Australia National Audit Office 2001, Contract Management: Better Practice Guide, Canberra, ACT, Australia.

Carr, J \& Exton, D 2004, 'Lyell McEwin Health Service Redevelopment Stage A: Case study', paper presented at the Clients Driving Innovation International Conference 2004,25- 27 October 2004, Surfers Paradise, Australia.

Christensen, D. and Walker, D. H. T. 2004. 'Understanding the Role of "Vision" in Project Success', Project Management Journal. vol. 35, no.3, pp.39-52.

Davis, P.R. (2004) 'Relationship Development in Construction Partner Selection', COBRA 2004,

The international construction research conference of the Royal Institution of Chartered Surveyors, 7-8 September 2004, Leeds Metropolitan University.

Davis, P.R. (2006) 'Relationship Development in Project Alliances', Presentation in the Austral an Institute of Project Management (AIPM) Semmar, 5 May 2006, Perth, Australia.

Department for Administrative and Information Services (DAIS) 2001, Adelaide Convention Centre Extensions project Completion Report, unpublished, Adelaide, South Australia.

Egan, J 1998, Rethinking construction : the report of the Construction Task Force to the Deputy Prime Minister, John Prescott, on the scope for improving the quality and efficiency of UK construction, Dept. of the Environment Transport and the Regions, London.

Latham, M 1994, Constructing the Team, HMSO, London.

Lynn, G. S. 1999. 'An Exploratory Study of Project Vision: Its Components and Impact on Innovation Success', International Journal of Innovation Management. vol.3, no.1, pp. 91-110.

Lynn, G. S. and Akgun, A. E. 2001. 'Project Visioning: Its components and impact on new product success', The Journal of Product 
Innovation Management. vol.18,no.6,pp.374387.

Quick, R 2002, 'Introduction to Alliancing and Relationship Contracting', paper presented at the QLS/BAQ Symposium 2002 - Session K, Construction Law, Queensland, Australia, 02 March 2002.

Ross, J 2001, Introduction to Project Alliancing (on Engineering and Construction Projects), viewed 12 Oct 2005,

$<$ http://www.fletcherconstruction.co.nz/article.php ?article id=103>.

Royal Commission into the Building and Construction Industry 2002, Overview of the Nature and Operation of the Building and Construction Industry,

<http://www.royalcombci.qov.au/>.

Rawlinson, S \& Cheung, FYK 2004, 'A Review of the Concepts and Definitions of the Various Forms of Relational Contracting', paper presented at the International Symposium of the CIB W92 on Procurement Systems: "Project Procurement for Infrastructure Constuction", 710

January, 2004, Chennai, India.
The Public Works Committee 1999a, Adelaide Convention Centre Extension: Final Report, Adelaide, South Australia.

The Public Works Committee 1999b, Agency Submission to The Public Works Committee of The Parliament of South Australia for the proposed Extensions to Adelaide Convention Centre, updated July 1999, viewed October 2005, $<$ http://www.parliament.sa.gov.au/committees/do cuments/PublicWorks/public documents/Reports /Arts.\%20Culture.\%20Sport.\%20Tourism/Report $\% 20105 \% 20-$ $\% 20$ Adelaide\%20Convention\%20Centre\%20ExV Agency\%20Submission.pdf>.

The Public Works Committee 2000, Official Hansard Report on the Adelaide Convention Centre Extensions project, 17 May 2000, Old Parliament House, Adelaide, South Australia.

Walker, DHT, Hampson, K \& Peters, R 2002, 'Project alliancing vs project partnering: a case study of the Australian National Museum Project', Supply Chain Management: An International Journal, vol. 7, no. 2, pp. 83- 91.

Walker, D. H. T. and Hampson, K. D. 2003. Procurement Strategies: A Relationship Based Approach.Oxford Blackwell 